\title{
PRESENTATION OF IMAGES IN DETECTIVE STORIES
}

\section{Koliasa O. V.}

\section{INTRODUCTION}

In detective stories an important character is a detective. The authors of these stories, trying to write such books, must find out about duties and responsibilities of real detectives in the country they intend to write about, in England, for example, they cannot wave weapons. Most of their actions are free of tension: they look for thieves in stores, follow unfaithful husbands or wives, look for the missing and get all the information their clients cannot get. For the needs of this genre of literature, the detective must be involved in murder. In old-fashioned stories, it happens that the ruffled police inspector calls for help a private detective to solve the case.

It is ironic that the stereotype of the method is transferred to the subject of research; there is an accusation here that detective story is schematic. A much greater sense of the essential features of the detective's stories has a more naive approach, for example in Cawelti's book ${ }^{1}$. In spite of the wide-scale theoretical assumptions and clear main weaknesses the results of typically American strain allowed Cawelti achieved more than the relatively narrow theoretical framework of his work.

According to J.G. Cawelti Hammett is artistically more convincing than Chandler, because for Chandler a source evil is only social depravity, while Hammett presents a deep cosmic vision of evil: a source of unhappiness it is indifferent, condemned to the randomness of the universe without $\mathrm{God}^{2}$. On the other hand Cawelti of course must acknowledge that Hammett, speaking explicitly political views was a radical - while Chandler's ideology is left-wing, although it still fits within the bourgeois limits of liberalism. From this contradiction Cawelti seems to rescue in such a way that contradiction for him simply means contradiction: against the radical political tendency Hammett has defined political tendencies as a deeper existential experience of the absurdity of human existence in a random universe without God. The absurdity of this, of course could not be finished by revolutionary upheaval in social relations, because it is deeper - it relies on the very deep relationship between the man and the universe.

It might be considered as paradox, that it is Hammett who sees the source of evil in the universe, and not only in the demoralization of

\footnotetext{
${ }^{1}$ Cawelti J.G., 1976. Adventure, Mystery and Romance. Chicago and London. ISBN 0226098672. P. 289.

${ }^{2}$ Cawelti J.G., 1976. Adventure, Mystery and Romance. Chicago and London. ISBN 0226098672. P. 289.
} 
society, expressing views political, explicitly raised the issue much more radically since Chandler: there are no bourgeois grievances for American corruption, rapacity, etc., but from the first novel Red Harvest Hammett gives definitive and clear description of class struggle, exploitation, capitalism as a way of production. Thus, it could be formulated direct answer in the spirit of historical materialism: the internal contradiction of Hammett's position can be explained as a contradiction between the chaotic irrationality of the existing of the society of monetary relations, the society in which there are more cases than rules, and the highest values change into contrary values but, on the other hand, a vision of its revolutionary change.

Cawelti's book, however, clearly outperforms most of theoretical literary work on the subject of a detective story, including authors' works, from whom, because of their interest, might be expected possibly a better sense of the specificity of the genre (e.g. W. Szkłowski and other contemporary continuators, above all I. Riewzin). An example of this type of work could be representative surveys so-called the Zagreb Comparative School, mainly Z. Skreb and V. Zmegać, whose dissertations on the subject of detective literature are also well known. Z. Skreb draws attention to two features that not allow the detective story treat as a work of art: 1) superhuman, actually divine infallibility of the intellect detective, i.e. the opposition of the irrational detective and realistic character the image of his environment; 2) the schematic of the genre as such - a writer must obey the predetermined pattern in events ${ }^{3}$. The question of whether a detective story is a work of art or not, is placed faultily. Basic paradoxes of artistic questioning the character of a detective story is that it is compared to so-called a realistic or psychological-realistic nineteenth century novel, then to state that it is not a work of art. Meanwhile, this model type of story after the avant-garde breakthrough at the beginning of $21^{\text {th }}$ century became artistically unreal.

Of course, it is not a coincidence that the final victory of the modern story over the traditional (twentieth) covers chronologically with the emergence of the form of the detective story, i.e. with shifting the focus from detective history for the novel: the detective story becomes historically possible only when it is impossible to create a traditional, psychological and realistic novel, therefore a comparative method has a completely unhistorical character if it compares both directly, if one assesses, taking the second as a model. In this way, naturally the differences are not denied in the artistic status between traditional realistic

\footnotetext{
${ }^{3}$ Zizek S., 1990. Logika powieści detektywistycznej, from Pamiętnik Literacki : czasopismo kwartalne poświęcone historii i krytyce literatury polskiej 81/3, 253-283 (retrieved Feb. 5, 2019)
} 
story and a detective story - important here is only the fact that art or the possibility of artistic affiliation should be each time historically concretized $^{4}$.

The problems of notorious omnipotence or omniscience of the detective story is particularly interesting: weakness of formulaic interpretations of the detective story becomes especially visible when it is needed to clear the detective position, the secret of the fact that the reader is convinced that the detective will finally explain the original riddle. Explanations are usually focused on two opposite directions: on the one hand the authors of these interpretations see the detective as a positive representative bourgeois rationality in its radical, a pure form; on the other hand, they recognize him as the heir of a romantic bard, a man who had an irrational, semi-supernatural power directly intuitive penetration of mystery, power unattainable by the common sense.

The scene of the crime appears at first glance to a detective in a homogeneous shape, which naturally assembled the perpetrator himself, to cover all traces. Also, the detective begins his analysis from searching for details that might fall out of the frame on this stage. It comes actually about the detail that is usually completely trivial (e.g. a broken cup, unexpected and involuntary attention, etc.), which, however, due to its structural nature evokes the destruction of the appearance of a homogeneous totality in which is subsumed, causing real alienation. "It's like moving a tiny fragment on well-known image, making it on the whole mysterious and unusual" (Mignon G. Eberhart). Of course, a clue can only be discovered by targeting, which is able to take the pressure of the imaginary in brackets - already Sherlock Holmes tells Watson: "Never take into consideration basic impressions, my dear, but reflect on the details, 5 .

Starting from the traces, the detective breaks the imagined uniformity of crime staged by the perpetrator, i.e., understands this uniformity as a reentangled assembly of heterogeneous elements, whereby the bond between the crime staged by the criminal in order the blurring of traces and the actual event corresponds exactly to the relationship between explicit content and the hidden thought of a dream or a dream between the direct image of the puzzle and its solution.

Also, one of the Russian literary theorist V.B. Shklovskyi drew attention to the fact that the privileged example of a double existence of the same feature is the word, the word play in fact. In the story Speckled Band

\footnotetext{
${ }^{4}$ Zizek S., 1990. Logika powieści detektywistycznej, from Pamiętnik Literacki : czasopismo kwartalne poświęcone historii i krytyce literatury polskiej 81/3, 253-283 (retrieved Feb. 5, 2019)

5 Doyle A.C., 2012. The Adventures of Sherlock Holmes - A Case of Identity. MX Publishing. ISBN 0486474917. P. 20.
} 
by A.C. Doyle the statement of a dying woman becomes the key to the solution: "That was a speckled band...", The wrong solution here is based on the wrong understanding word band which is understood closer to word gang (particularly because there is a group of Gypsies camping near the place of homicide) and there is already a vivid, exotic image of bloodthirsty Gypsies. The real solution is, of course, to understand band as ribbon or blindfold. Of course, the role of doubly understood elements might play (and in most cases play) non-linguistic material, which in this case is already structured as the speech (Shklovsky cites the story of Chesterton, where it is fulfilled this function by evening suit and outfit of a valet). However, it is important that the spread between the public scene initiate by the criminal, and the muffled truth justify the structural need for a false solution (to which a reader is led by a deceptively open scene and what police or other authorities are usually taken in). It precedes immanently true detective solution: the wrong solution is consistent with its epistemologically internal status in relation to a real solution.

\section{Main character is a detective?}

The detective does not propose the right answer right away, but allows formulate one or more wrong solutions earlier (solutions, which are imposed due to the criminal's staging). However, the key issue for this detective method is that he has no external attitude for these erroneous solutions, he does not see in them only a mistake, which should be rejected in order to reach the truth. The detective himself needs this erroneous resolution, because the correct one can come only thanks to him: the direct path to the right solution is not there. This is, by the way, a classic meaning of detective stories, the character of a naive detective companion, usually narrator (Watson accompanies Holmes, Hastings - Poirot).

This problem was completely clear to Agatha Christie: in one of her stories desperate Hastings asks why Poirot needs him, since he is a completely ordinary man, he has the most usual prejudices, he is not distinguished by reason. Poirot's answer is crucial and it sounds more or less like this: Hastings is needed just because he is an ordinary person with ordinary reactions, and thus embodies what could be called doxa, an uncomplicated, spontaneous ideological opinion ${ }^{7}$. When a criminal commits a crime, he must - after all, to cover all traces, plan to construct a false image of a crime, make a crime the work of someone else and to make the true motive unclear (classic topos: murder is committed by a

\footnotetext{
${ }^{6}$ Doyle A.C., 2012. The Speckled Band. Troll Communications Lic. ISBN 0893756199. P. 25.

${ }^{7}$ Preus A., 2007. Historical Dictionary of Ancient Greek Philosophy. Lanham, Maryland, Toronto, Oxford. The Scarecrow Press Inc. ISBN 978-0-8108-5487-1. P. 128.
} 
close relative of the victim, depicting it as the action of burglars, whose victim were supposedly surprised $)^{8}$. Here it might be a question: who exactly wants to fool the criminal with this false image, on whom the criminal relies by creating this picture? It is, of course, the field of just mentioned doxa, for the colloquial opinion embodied in the character of a detective companion: Watson or Hastings. In other words: the detective do not need Watson to strut detective's mind but because Watson's naive usual reactions have revealed a false image, the same image what was the offender intention.

In The ABC Murders by Agatha Christie there are series of murders running according to a complicated alphabetic key; for first glance is obvious that it is a pathological type of criminal. But Poirot solves this case completely differently: the murderer really wanted to kill only one victim and not because of a pathological cause, but because of very rational, material benefits; and to blur the motive of his deed, he killed several people before an insane key, which should have led the police to a false clue and looking for a madman'. In The Red-headed League by Arthur Conan Doyle, a red-haired man reports to Holmes and tells him about an extraordinary adventure: he read the ad in which a man with red hair was offered a well-paid job by a few hours a day; he volunteered, and then from many candidates his was chosen. The work was exceptionally senseless: he had to write fragments of the Holy Bible every day. After joining to work, Holmes quickly stated what the ambush was: next to it the residence of the red-haired man was a large bank. The criminals gave an advertisement to the newspaper because they expected to report also this man; of course he was accepted. In fact the criminals only meant that during his absence they dig under his apartment the tunnel leading to the bank; the red-headed man was only a coincidence, cleverly used by criminals ${ }^{10}$.

What is common in both examples? The first impression evokes an image of a pathological, extravagant construction which, according to an insane key (red hair color, an alphabet) covers a wider circle people, in fact it is only about one person who should be lured from the apartment or killed. Delving into the hidden meaning does not lead to the solution (what it would mean limiting to people with red hair, why more murders have an alphabetical order?) if thoughts are running in this direction, a reader might fall into a trap. The only real way is rejection the surface and focusing more on details.

\footnotetext{
${ }^{8}$ Słownik języka polskiego PWN. URL: www.sjp.pwn (retrieved Feb. 7, 2019)

${ }^{9}$ Christie A., 2017. The ABC Murders. Wydawnictwo Dolnośląskie. ISBN 9788324589524. P. 144.

${ }^{10}$ Doyle A.C., 1992. Red-Headed League. Warszawa. ISBN 0723578281. P. 54.
} 
Here could be a question: why for this absurd work, such an individual was accepted, omitting it the fact that there is a reason for it? Who would benefit from the death of one of murdered people, and what means an alphabetical order of the names of the victims? In other words, all the time should be awareness that these semantic fields of meaning exist for the reason to hide their cause of existence. The meaning of the game with redheads lies solely in the fact that the victim of this game, the chosen red-haired man, thought that his red hair really have a meaning in all of this; the importance of the game with the alphabet is that the police think that the initial letters of the names of murdered people do matter.

In the detective approach completely wrong is a search for the method of a strict natural-analytical mind: of course, an objective researcher will also reach for the hidden truth, but the area he is dealing with lacks dimension of deception, after all, it could not be said that an object of research wants to cheat the researcher, i.e. the area with which directly the objective researcher meets, exists only to hide reason for its existence. The detective - in opposition to the objective researcher - reaches the truth in the way that simply removes cheating, but calculates it.

The truth is not on the side of the crime, the truth is in intention, in intersubjective setting of the crime itself. The detective does not eliminate the meaning of a false image, but it brings out its self-reliance, leading to the point where it turns out that "the meaning (of a false image) lies in the fact that (others they think that) is important." At this point, where the offender position is about declaring "I cheat you", the detective can return him "his own statement in its true meaning"". Hence, of course, the famous omnipotence or omniscience of the detective is appearing in a different light: the earlier certainty that the detective will solve the problem is not based on the fact that "it will come to the truth no matter what for all deceptive appearances" but in the fact that he will catch readers on his own deception that he will calculate the existence of a crime. Detective function therefore can be compared to the role of the analyst as the entity of which it is believed that he knows.

The scene with which the detective has to act, which he analyzes, is structured as speech, i.e. it is a significant network: the detective moves at the level of meaning, not at the level of facts. The detective is already at the level of a priori intersubjective relationship: one of the constitutive orders the genre is that the corpse cannot appear as a result of an unhappy one accident, but must produce it as subjective as possible perpetrator

${ }^{11}$ Zizek S., 1990. Logika powieści detektywistycznej, from Pamiętnik Literacki : czasopismo kwartalne poświęcone historii i krytyce literatury polskiej 81/3, 253-283 (retrieved Feb. 7, 2019) 
(not a professional criminal, and not also in detective stories all crimes should be committed because of personal motives).

The detective reconstructs the significant network, his activity depends mainly on the differential method: in the absence itself he sees the presence of this absence, the vacuum itself is positive for the detective. Signs that raise suspicion are read as elements of speech. It is not a coincidence, when in the most famous dialogue Sherlock Holmes is talking to Silver Blaze: "You consider that to be important?", "Exceedingly so.", "Is there any point to which you would wish to draw my attention?", "To the curious incident of the dog in the night-time.", "The dog did nothing in the night-time.", "That was the curious incident," remarked Sherlock Holmes ${ }^{12}$. In this way, the detective captures the perpetrator: the center of balance point does not rest on the traces that the offender failed to erase, but on that the detective no longer sees any traces as a trace.

The detective's role as a subject who is supposed to know the truth about crime, could therefore be defined as follows: the scene of the crime offers many clues, meaningless elements collected without any rules, and the detective himself with its presence guarantee that the result of the fact will gain the meaning.

The detective's special position as a guarantor of significance allows understand the circularity of a detective story: at first there is a weak point, emptiness, the whiteness of the unexplained (how it really is has a crime been committed?), the story revolves around what is unsaid or what happened before the crime, i.e. the course of events forces the detective to follow symptoms to reconstruct the authentic, missing history - the history of a crime.

The story of a detective's investigation is, therefore, like selfreflective history of an attempt to reconstruct true facts and therefore the real beginning could be reached only at the end and might be completed when the detective can tell the whole missing story in a normal, linear shape, that is, when the reconstruction is succeed, and all empty spaces are filled. At the beginning there is a murder - trauma, which cannot be assimilated into symbolic reality, an event that cannot be integrated into a given reality, which falls out of the causality of what is normal.

The greatest strength of a detective story lies undoubtedly in its own kind of alienation effect produced by it. Idyllic naturalness (ideological) everydayness loses its obviousness and in the traumatic light the fact of the murder begins to appear as an illusory effect of hidden artificial mechanisms. In the most known objects and situations, notes made casually, accidentally found trifles, etc., it might be seen potential movers

${ }^{12}$ Doyle A.C. Silver Blaze. URL: www.eastoftheweb.com / (retrieved Feb. 10, 2019) 
of horror, fear because "anything - could mean anything possible". Such alienation effects are connected with some assumption: with the existence of a specific - although very misleading - normality and security.

This normality (idyllic English town, exotic company collected in a provincial palace, etc.), of course, is not ultimately nothing else but the ideological appearance of the naturalness of society bourgeois. The detective is not the guardian of the existing order only because at the end with his help the perpetrator is eliminated, the idyllic everyday life is coming back, but maybe still more so because the crime itself gives a strict interpretation of anthropocentrism of bourgeois society: the only legitimate motives of crimes are money and love. Therefore what only enters into the equation is a natural motif of bourgeois society - possession.

The question about the so-called the social roots of murder is banned in the classic detective story - at least as a rule - a killer cannot be associated with any organization (e.g. mafia). The second, hidden side revealed by the detective, is not less ideological than the surface of idyllic everyday life: it is precisely ideological mirror image - the world of absolute selfish individuals.

Thanks to the detective story the gap between the idyllic surface and its hidden side is getting smaller. The social environment is directly represented in it as a world of selfish individuals, wealth and social careers (for example in James Caine's novels), a world in which all glorification is only a manifestation of external conformism or even cunning mystification. Split between the classical world and the world of the detective stories occurs on the surface area. The story drops a mask of "normality and security - even very misleading".

A lack of that surface mask shifts the entire system: the detective's status is radically changed. A detective is no longer an analyst who thanks to the logic and deduction is moving through the appearance of idyllic everyday life to its hidden side, but he is an active hero who faces the chaotic and depraved world. He is involved into the game from the very beginning, captured through it, and yet, to solve mysteries, he is pushed to settle a debt.

The above statement could be understood in the entire spread: from a subtle intersubjective dialectic, a wounded sense of subjectivity which attempts to give satisfaction to Chandler's Philip Marlowe, to the primitive ethics of revenge in Mickey Spillane's behaviour. As a result, the detective loses this natural eccentric enabling position to act as a kind of subject in the situation, in which he is supposed to be involved.

Such interpretation determined that the classic detective story is almost never written in the first person with the detective as a narrator, but 
in the form of a story impersonal, or a narrator - a detective companion (character of Dr Watson) or some attractive representative of the environment social, a person, for whom the detective is a subject.

In the classic detective story there is a strict prohibition of directly presenting the inner course of detective thoughts. The thought process in his brain to the final solution must remain inaccessible, limited to a single mysterious remark or questions that will naturally underline the inaccessibility what's going on in the detective's head.

A real master of such stylistic figures, which, unfortunately, sometimes approaches mannerism is Agatha Christie, e.g. Poirot in a complicated investigation puts the inquiry in an eccentric tone like: "By coincidence do not you know what color the maid's stockings were?" and after hearing the answer, he mysteriously murmurs: "So everything is clear!". It is worth recollecting a dialogue from the novel by N. Meyer The Seven Per Cent Solution, which is a pastiche of S. Holmes's adventures. Sherlock Holmes says in it: "War is on in Europe, it's obvious. - But how can you draw such a conclusion based on what you saw today? - From the relationship between Baroness Leinsdorf and her adopted son.". The situation is explained at the end when the detective with a hint of victory in the voice indicates the perpetrator and then tells the whole story in a linear shape. In other words, if the issue is considered from the point of view of the reader, in the classic detective story there is never the identification with the detective, but with a structural necessity, that is, a narrator or a person for whom the detective is a subject who is supposed to know - and if the solution is too obvious, if a reader does not want to be deprived of satisfaction from reading, he must try to believe cheating, even if it will be very naive.

\section{The most noted detectives in classic literature}

Many detective stories' authors implemented to the literature unforgettable detective characters, e.g. A.C. Doyle who figured out Sherlock Holmes. Holmes was a brilliant detective who used a deduction in solving the mystery. The novelty of Holmes's investigations is in his revealing the truth in the light of observations, psychology, chemistry, ballistics or mathematics. Many times he was guided by intuition. Holmes was also talented violinist and boxer. He was mostly self-possessed, rarely reveal his feelings, and news of his friend Watson's engagement made him to say: Love is an emotional matter, and everything that is emotional is the opposite of cool reason, which I value above all else. I will never marry myself unless something changes my mind $^{13}$.

\footnotetext{
${ }^{13}$ Stories : Sherlock Holmes. URL: www.sherlock-holm.es/stories/pdf (retrieved Feb. 11, 2019)
} 
S. Holmes was a heavy smoker and despite being warned from his friend Watson was also addicted to drugs. Holmes believed that tobacco, morphine and cocaine enable him to think clearly. Every investigation was a real challenge to him and made him vigorous. That may be illustrated by Watson's words about Holmes: One night - it was on the twentieth of March, 1888 - I was returning from a journey to a patient (for I had now returned to civil practice), when my way led me through Baker Street. As I passed the well-remembered door, which must always be associated in my mind with my wooing, and with the dark incidents of the Study in Scarlet, I was seized with a keen desire to see Holmes again, and to know how he was employing his extraordinary powers. His rooms were brilliantly lit, and, even as I looked up, I saw his tall, spare figure pass twice in a dark silhouette against the blind. He was pacing the room swiftly, eagerly, with his head sunk upon his chest and his hands clasped behind him. To me, who knew his every mood and habit, his attitude and manner told their own story. He was at work again. He had risen out of his drug-created dreams and was hot upon the scent of some new problem. I rang the bell and was shown up to the chamber which had formerly been in part my own ${ }^{14}$.

As mentioned before a detective was also asked for help local police to conduct investigation. That was sometimes S. Holmes's tasks as well: Holmes, who loathed every form of society with his whole Bohemian soul, remained in our lodgings in Baker Street, buried among his old books, and alternating from week to week between cocaine and ambition, the drowsiness of the drug, and the fierce energy of his own keen nature. He was still, as ever, deeply attracted by the study of crime, and occupied his immense faculties and extraordinary powers of observation in following out those clues, and clearing up those mysteries which had been abandoned as hopeless by the official police ${ }^{15}$.

A. Christie brought to life two detectives who, along with Sherlock Holmes, permanently signed up on the pages of literature. They are of course Hercules Poirot and Miss Jane Marple. A retired policeman from Belgium became famous for having a fondness to symmetry. He repeatedly proved that sometimes a cool analysis of facts can be more effective than collecting fingerprints. He was often accompanied by Captain Hastings as a reflection of a naive reader who catches all the clues and gropes for a solution, ignoring the logical cause and effect sequence. Poirot was presented for the first time in The Mysterious Affair at Styles (1921) and figured in more than thirty A. Christie's books. Poirot worked as a police

\footnotetext{
${ }^{14}$ Stories : Sherlock Holmes. URL: www.sherlock-holm.es/stories/pdf (retrieved Feb. 11, 2019)

${ }^{15}$ Stories : Sherlock Holmes. URL: www.sherlock-holm.es/stories/pdf (retrieved Feb. 11, 2019)
} 
officer in Belgium, but after I world war he moved to Britain and started to work as a private detective. Christie gave him characteristic features such as low growth, eggy head, well-groomed moustache, dandy cloths, obsessed with order and symmetry as well disdain for classical methods of investigation: Poirot was an extraordinary looking little man. He was hardly more than five feet, four inches, but carried himself with great dignity. His head was exactly the shape of an egg, and he always perched it a little on one side. His moustache was very stiff and military. The neatness of his attire was almost incredible. I believe a speck of dust would have caused him more pain than a bullet wound. Yet this quaint dandyfied little man who, I was sorry to see, now limped badly, had been in his time one of the most celebrated members of the Belgian police. As a detective, his flair had been extraordinary, and he had achieved triumphs by unravelling some of the most baffling cases of the day ${ }^{16}$.

He always relied on grey cells to determine who commit the crime: "These little grey cells. It is'up to them - as you say over here", ${ }^{\prime 7}$. Similarly to other Golden Age detectives he was not being married. H. Poirot was created as a rich person who had connections with aristocracy, the royal family, Prime Minister and other influential people ${ }^{18}$.

Another detective created by A. Christie was Miss Marple, a resident of the provincial St. Mary Mead who was an elderly lady with a tendency to observe and associate facts. Encountered people reminded her of the events of the past, she could find an analogy between them and work out the murderer: "It also shows that the murderer was well acquainted with Old Hall and its surroundings. It wasn't Mrs. Protheroe who put that call through. I've accounted for every moment of her time that afternoon. There are half a dozen servants who can swear that she was at home up till fivethirty. Then the car came round and drove Colonel Protheroe and her to the village. The colonel went to see Quinton, the vet, about one of the horses. Mrs. Protheroe did some ordering at the grocers and at the fish shop, and from there came straight down the back lane where Miss Marple saw her. All the shops agree she carried no handbag with her. The old lady was right",19.

It is worth mentioning also about other Christie's characters Tommy and Tuppence, firstly in love with a couple, then a marriage with a group of grandchildren. In their youth, they acted in the British Secret Service, they also established a detective agency and even retired when they hunted

\footnotetext{
16 Mystrious Affair. URL: www.f.waseda.jp/glaw/CLASSES/MysteriousAffairAtStyles.pdf (retrieved Feb, 12, 2019)

${ }^{17}$ Ibidem

${ }^{18}$ Hercule Poirot. URL: www.HerculePoirot-amateurdetective.Famousdetectives (retrieved Feb. 12, 2019)

${ }^{19}$ A. Christie. URL: www.detective.gumer.info/anto/christie_33_2.pdf (retrieved Feb. 13, 2019)
} 
villains: Tuppence sighed and closed her eyes dreamily. "So Tommy and Tuppence were married," she chanted, "and lived happily ever afterwards. And six years later they were still living together happily ever afterwards. It is extraordinary," she said, "how different everything always is from what you think it is going to be",20.

In opposition to presented detective characters in detective fiction appears another character who provides investigations. It is Philip Marlowe created by Raymond Chandler. Marlowe is an ex-police officer and prosecutor who was fired from job because of his big mouth. In contrast to e.g. Holmes or Poirot P. Marlowe investigates among so called underworld. The novelty is that Chandler describes gloomy world where the moral collapse could be seen everywhere: "Two more swing doors closed off the head of the stairs from whatever was beyond. The big man pushed them open lightly with his thumbs and we went into the room. It was a long narrow room, not very clean, not very bright, not very cheerful",21. "The rest of the house would be just rooms. There was a dirty garbage pail on the small porch and a wooden box full of liquor bottles. Behind the screen the back door of the house was open. It was gloomy inside $^{, 22}$.

Crimes in his stories are pervasive and such idealist as Marlowe who has many weaknesses by the way, is trying to fight with those delinquencies ${ }^{23}$. In Chandler's fiction Marlowe is the only character who fulfils justice and on his own must punish offenders: "I told her a little," he said coldly. "For a reason. I'm calling you for the same reason. This investigation is going to be undercover. We have a chance to break this

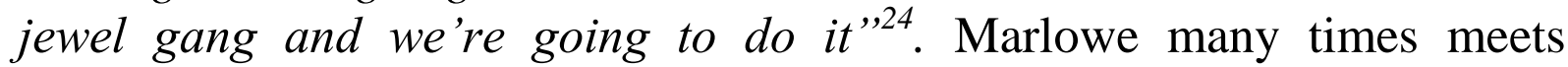
corrupted police officers, gangsters or influential people but no one and nothing is able to disturb him in task performance: He sat very still for a moment, then leaned forward and pushed the gun across the desk to me. "The things I do," he mused, as if he was alone. "I run towns, I elect mayors, I corrupt police, I peddle dope, I hide out crooks, I heist old women strangled with pearls. What a lot of time I have." He laughed shortly. "What a lot of time" 25.

20 A. Christie : partners in crime. URL: www.educatora.in/uploads/2/0/5/1/20513864/partners_in_ crime_by_agatha_christie.pdf (retrieved Feb. 13, 2019)

${ }^{21}$ Chandler R.. Farewell my lovely. URL: www.ae-lib.org.ua/texts-c/chandler_farewell_my_lovely__ en.html (retrieved Feb. 13, 2019)

${ }^{22}$ Chandler R.. Little sister. URL: www.gutenberg.ca/ebooks/chandlerr-littlesister/chandlerr-littlesister01-h.html (retrieved Feb. 13, 2019)

${ }^{23}$ Philip Marlowe. URL: www.PhilipMarlowe-privateinvestigator.Famousdetectives (retrieved Feb. 13, 2019)

${ }^{24}$ Chandler R.. Farewell my lovely. URL: www.ae-lib.org.ua/texts-c/chandler_farewell_my_lovely__ en.html (retrieved Feb. 13, 2019)

${ }^{25}$ Chandler R.. Farewell my lovely. URL: www.ae-lib.org.ua/texts-c/chandler_farwell_my_lovely_en.htm (retrieved Feb. 14, 2019) 
Another author who left the mark on detective story subgenre is Dashiell Hammett. He created Sam Spade - a private detective who is presented in The Maltese Falcon (1930). In that story a detective character is presented differently from classical private detectives e.g. S. Holmes or H. Poirot. D. Hammett describes him in such words: Spade has no original. He is a dream man in the sense that he is what most of the private detectives I worked with would like to have been and in their cockier moments thought they approached. For your private detective does notor did not ten years ago when he was my colleague - want to be an erudite solver of riddles in the Sherlock Holmes manner; he wants to be a hard and shifty fellow, able to take care of himself in any situation, able to get the best of anybody he comes in contact with, whether criminal, innocent by-stander or client ${ }^{26}$.

Sam Spade was presented as a relentless, brash and hardheaded man who could be the only person to explain the crime: Luke grunted and stood up saying: "You're a tough one to figure out, Sam. Come on, we'll have that look-see,"27. For some literature critics S. Spade is classified as an antihero, because he did not care much for conventional behaviour or morals. Although Spade had all attributes ascribable to heroes in literature such as courage, skillfulness, sacrifice, destination but he did not occur them in an orthodox way. Nevertheless he had enough courage to solve the mystery of the Maltese Falcon and his partner's murder. His attitude was: "When a man's partner is killed he's supposed to do something about it. It doesn't make any difference what you thought of him. He was your partner and you're supposed to do something about it. Then it happens we were in the detective business. Well, when one of your organization gets killed it's bad business to let the killer get away with it. It's bad all around-bad for that one organization, bad for every detective everywhere. Third, I'm a detective and expecting me to run criminals down and then let them go free is like asking a dog to catch a rabbit and let it go. It can be done, all right, and sometimes it is done, but it's not the natural thing ",28.

Another interesting trait of S. Spade is that he seemed to have no respect to authority or to the police: "If we don't give the police a fall-guy it's ten to one they'll sooner or later stumble on information about the falcon. Then you'll have to duck for cover with it - no matter where you are - and that's not going to help you make a fortune off it. Give them a

\footnotetext{
${ }^{26}$ Hammett D., 1988. The Maltese Falcon. Wrocław. Wydawnictwo Iskry. ISBN 0679722645. P. 12.

${ }^{27}$ Hammett D. URL: www.gutenberg.ca/ebooks/hammettd-maltesefalcon/hammettd-maltesefalcon-00-h.html (retrieved Feb. 14, 2019)

${ }^{28}$ Hammett D. URL: www.gutenberg.ca/ebooks/hammettd-maltesefalcon/hammettd-maltesefalcon-00-h.html (retrieved Feb. 14, 2019)
} 
fall-guy and they'll stop right there" ${ }^{\text {"29 }}$. Even though Spade had residues of self-control and a sense of justice that the guilty should to be punished: "Blood streaked Spade's eyeballs now and his long-held smile had become a frightful grimace. He cleared his throat huskily and said: "Making speeches is no damned good now." He put a hand on her shoulder. The hand shook and jerked. "I don't care who loves who I'm not going to play the sap for you. I won't walk in Thursby's and Christ knows who else's footsteps. You killed Miles and you're going over for it. I could have helped you by letting the others go and standing off the police the best way I could. It's too late for that now. I can't help you now. And I wouldn't if I could."

She (Brigid O'Shaughnessy) put a hand on his hand on her shoulder. "Don't help me then," she whispered, "but don't hurt me. Let me go away now."

"No," he said. "I'm sunk if I haven't got you to hand over to the police when they come. That's the only thing that can keep me from going down with the others" 30 .

A kind of combination of two presented famous detective protagonists - Sherlock Holmes and Sam Spade is another fictional character from the cycle of detectives stories by Georges Simenon private detective Jules Maigret also called as Sherlock Holmes of France. That description given to Commissioner Maigret, and in terms of worldwide popularity, it certainly deserves to be attended by the most famous British detective. The similarities do not end here. Like Sir A.C. Doyle Georges Simenon tried to get rid of his detective in the early stages of the series, underestimating his great interest in readers who immediately insisted on his return. Both authors, since their death, have been greatly eclipsed by the icons they created.

Maigret is one of the selected literary characters recognizable under one name and really became a cult figure. 84 novels and 18 short stories that Simenon wrote about him give a fairly clear image of him but there are still enough enigmatic aspects of his character and mysterious elements to intrigue and fascinate subsequent generations of readers. Over the years, Maigret has also become a phenomenon. He was the subject of scientific works, and literary parody, the subject of fan letters, inspiration for many films and TV series.

Maigret was depicted as rather unpleasant, but completely unforgettable. Maigret was 5 feet tall and 11 inches wide, his broad

\footnotetext{
${ }^{29}$ Hammett D. URL: www.gutenberg.ca/ebooks/hammettd-maltesefalcon/hammettd-maltesefalcon-00-h.html (retrieved Feb. 14, 2019)

${ }^{30}$ Hammett D. URL: www.gutenberg.ca/ebooks/hammettd-maltesefalcon/hammettd-maltesefalcon-00-h.html (retrieved Feb. 14, 2019)
} 
shoulders and stiff features reflect his bourgeois origins: Maigret did not move. He was a head taller than his fellow passengers. (...) A powerful silhouette emerged from the shadows: Commissioner Maigret in a dark cloak with a velvet collar, hands in pockets. (...) Maigret was too wide in the bars, for this cramped and cluttered room. It seemed to fill the entire space, obscuring the light ${ }^{31}$.

At the beginning of his career, the inspector wore a thick mustache, dressed in a well-tailored suit and a thick winter coat with a velvet collar, and rarely without the most British equipment, bowler. But when he became a commissioner, Maigret decided to change the police fashion by adopting a mackintosh and a hat and shaving a mustache.

Detective Maigret is described by Simenon as a person addicted to smoking a pipe: "Maigret did not take a nap, despite half-closed eyes and a quenchless pipe that he did not take out of his mouth"32; lovers of sophisticated alcohols: "Maigret with a glass in his hand (...) tasted vermouth, never ceasing to talk",33; and also a mixed approach to investigation:

He was confused, looking around with fear.

- Did not take any guests? Your son, for example?

- No... You came. Then we ate supper. Later ...

- What's next?

- Nothing... I do not know... It happened alone. She is very sensitive. There have been so many misfortunes in life!

Did he really believe what he was saying? Maigret took the impression that he speaks to convince himself ${ }^{34}$.

Sometimes he relied on pure intuition but many times he used specific methods to reveal a crime. In opposition to earlier detective stories where the main character was a brilliant private detective and the action took place in closed higher-class milieu commissioner Maigret conducted investigations procedures performed by the state police apparatus ${ }^{35}$. Maigret's investigations were based not only on his above-average (though seemingly invisible) intelligence and charisma, but also on the police routine, archives and work under the commissioner of junior inspectors. Each of the stories about commissioner Maigret is a fresco of the life of the Paris suburbs or the French province. In most of the stories, Paris is clearly portrayed, its transformations over more than three decades, various environments - from the bourgeoisie and the official circles to the lumpen proletariat. Readers go along with the

\footnotetext{
${ }^{31}$ Simenon G. URL: www.gutenberg.ca/ebooks/simenon-L'ombre chinese.html (retrieved Feb. 14, 2019)

${ }^{32}$ Simenon G. URL: www.gutenberg.ca/ebooks/simenon-L'ombre chinese.html (retrieved Feb. 14, 2019)

${ }^{33}$ Simenon G. URL: www.gutenberg.ca/ebooks/simenon-L'ombre chinese.html (retrieved Feb. 14, 2019)

${ }^{34}$ Simenon G. URL: www.gutenberg.ca/ebooks/simenon-L'ombre chinese.html (retrieved Feb. 14, 2019)

${ }^{35}$ Żabski T. (red.), 1997. Stownik literatury..., op. cit., p. 45.
} 
commissioner through Pigalle square (Maigret and the corpse of a young woman), look into low-budget hotels in search of some street girl who witnessed the crime: Maigret with hands in his pockets stood at the edge of the sidewalk, thinking that Ponthieu Street looked a bit like a backstage or the Champs-Elysées kitchen stairs. Every great Parisian artery has that, often running parallel, narrower and more mobile street, where small bars are located and grocery stores, chauffeur restaurants and cheap small hotels, hairdressers and dozens various service workshops ${ }^{36}$.

Simenon provides many other interesting details about Maigret, too. He has a unique sight, essential for any good detective. Due to the demands of his work, he learned that he was able to catch a short sleep almost everywhere. He is prone to claustrophobia, and excessive effort sometimes causes a lack of breath: It was short dry sound. It is not Maigrel's broken pipe cracked under the pressure of his teeth. The pipe's head fell to the ground, Maigret bent to pick it up and put it in his pocket. - I'm sorry, it is stronger than me. - An even breath came back to him, he wiped his eyes; he glanced at the bottle of cognac, he did not dare to reach it ${ }^{37}$.

What makes this sometimes slow moving and rather large detective is so different? Above all, he is a sympathetic man. He has perfect insight into human nature, he is often fallible, he has an excellent approach to the crime. From the usual police inspector's methods, he definitely prefers to interview or question personally than to bring suspect to his office. He goes, looks, smells, touches, senses, feels the situation and the people he is dealing with. He inevitably is involved in action, tension, danger, laughter - and he sees it all through the sight of an extraordinary humanity.

Summarizing the novelty of detective stories' characters is that all provide investigation in their own style. Some of them are elegant detectives with impeccable manners while others seem to be rather abrupt, but they have a corporate goal: to reveal the truth and punish the villain. They strongly believe that world should be cleaned from such offensive individuals to be a better place to exist.

\section{CONCLUSIONS}

Detective story, extended with a social and moral background and great psychological portraits of criminals and positive heroes, is that it becomes a psychological story also.

Analyzing the system of images of detective stories, it can be proved that one or two main characters appear in a story (mostly police officers, prosecutors, lawyers, journalists, psychologists or profilers). Each part is

\footnotetext{
${ }^{36}$ Simenon G. URL: www.gutenberg.ca/ebooks/simenon-Maigretetlajeunemorte.html (retrieved Feb. 15, 2019)

${ }^{37}$ Simenin G. URL: www.Simenon/Georges/Maigret Hesitates.pdf (retrieved Feb. 15, 2019)
} 
based on a crime, but side stories are equally important, thanks to which the reader learns the fate of the detective hero.

One of the basic principles of telling a story is vivid in a detective story: cause and effect. In detective stories a reader notices more than in any other genre that each scene must be justified - each fiction event must be right in the story, because a reader or an audience perceive each scene as a potential cause of the effect that appears later.

\section{SUMMARY}

This article deals with the image building of detective stories. The aim of the research was to provide the analysis, comparison of the most noted detectives in classic literature, and also presenting the characteristic features of them.

The analysis of each chapter presented above was achieved on the basis of extracts from the detective stories of the best-known authors such as: E.A. Poe, Sir A.C. Doyle, A. Christie, R. Chandler, D. Hammett, G. Simenon, J. Skvorecky, J. Nesbo, M.S. Andrews, J. Alex, and N. Randon.

\section{REFERENCES}

1. W.H. Auden. Notes on the detective story, by an addict. Harper's Magazine, April 8. 2019.

2. R. Chandler. The Long Goodbye. VintageCrime / Black Lizard, 1988.

3. A. Christie. The Mysterious Affair at Styles. 1920, retrieved from: http://www.gutenberg.org/ebooks

4. A. Christie. Mrs. McGinty's dead, 1952, retrieved from: www.eslstudyguideresources.com/pdf

5. A. Christie. Murder in the Mews. London. Fontana, 1964.

6. A. Christie. Murder on The Orient Express. Wydawnictwo Hachette, 2000.

7. A. Christie. An Autobiography. William Morrow Paperback. London, 2012.

8. A. Christie. The ABC Murders. Wydawnictwo Dolnośląskie, 2017.

9. A. C. Doyle. The Adventures of Sherlock Holmes - A Case of Identity. MX Publishing, 2012.

10. G. Simenon G. The Hatter's Ghost, retrieved from: www.googlebooks.com

11.P. Stachura. Noc przed rozpoznaniem - typologia rozpoznania w fabule kryminalnej [w] "Podteksty", 2006, retrieved from: www.katalog.czasopism.pl/index.php/Podteksty

12. Detective Stories. www.detective.gumer.info/anto/christie_8_2.pdf 
13. Partners in Crime by A. Christie. www.educatora.in/uploads/ 2/0/5/1/20513864/partners_in_crime_by_agatha_christie

14. Chendler. Little Sister. www.gutenberg.ca/ebooks/chandlerrlittlesister/chandlerr-littlesister-01-h.html

15. The Murder of Roger Ackroyd. www.harpercollins.com/themurder-of-roger-ackroyd

16. Famous Detectives. Hercule Poirot. www.HerculePoirotamateurdetective.Famousdetectives

17. Famous Detectives. Philip Marlowe. www.PhilipMarloweprivateinvestigator.Famousdetectives

18. Sherlock Holmes Stories. www.sherlock-holm.es/stories/pdf

19. G. Simenon. Maigret. www.Simenon/Georges/Maigret Hesitates.pdf

Information about the author: Koliasa O. V.,

Candidate of Philology, Associate Professor at the Department of Germanic Languages and Translation, Drohobych Ivan Franko State Pedagogical University 24, Ivan Franko str., Drohobych, 82100, Ukraine 